\title{
Die ekonomie van die antieke platteland ${ }^{1}$
}

\author{
G J Volschenk \\ Navorsingsassosiaat: Departement Nuwe-Testamentiese Wetenskap \\ Universiteit van Pretoria
}

\begin{abstract}
The economy in the agrarian society

This article is an introduction to a three part series on the ancient economy. The conflict theory is the reference framework for the interpretation of the first century Palestinian society. The broad characteristics of the agrarian society are being discussed. Two aspects of the ancient economy, namely production and distribution of resources and goods are discussed. Lastly, the ancient economy can be interpreted within a holistic and systemic-interrelated model. The model shows the place and function of the economy in the ancient society.
\end{abstract}

\section{INLEIDING}

Die artikel is die eerste van drie en dien as inleiding tot die reeks oor die antieke ekonomie. Die konflikteorie dien as verwysingsraamwerk vir die eerste-eeuse Palestynse samelewing. Die brëe trekke van die agrariese samelewing, wat ontwikkel het vanaf 'n simplistiese agrariese samelewing na 'n gevorderde agrariese samelewing, word kortliks bespreek. Twee fasette van die antieke ekonomie, naamlik produksie en die verspreiding van lewensmiddele en goedere, word verduidelik. Laastens word 'n holistiese en sistemiesinterrelasionele model daargestel waarbinne die antieke ekonomie geïnterpreteer kan word. Die plek en funksie van die ekonomie word binne hierdie model aangetoon.

\footnotetext{
1 Dr Gert $\mathrm{J}$ Volschenk (MDiv, DD) is as navorsingsassosiaat betrokke by prof dr Andries G van Aarde se navorsingsprojek "Bybelse Teologie en Hermeneutiek", Departement Nuwe Testamentiese Wetenskap, Fakulteit Teologie, Universiteit van Pretoria.
} 


\section{KONFLIKTEORIE EN DIE ANTIEKE SAMELEWING}

Oakman (1991:151-179) gee 'n uiteensetting van die plek en funksie van die platteland binne die eerste-eeuse Mediterreense wêreld. 'n Absolute digotomie (of antagonisme - GV) tussen die stad en platteland is nie duidelik aanwysbaar nie. Die sosiologie gee duidelike aanduidings van 'n belangrike verskil tussen die twee gebiede (Oakman 1986:78; 1991:153; Fager 1993:86). Die konflikteorie ${ }^{2}$ as model vir die platteland word verkies bo die struktureel-funksionalistiese benadering (kyk Van Staden 1991:105-145 vir 'n verduideliking van die onderskeid tussen bogenoemde twee benaderings). Laasgenoemde benadering kan soos volg beskryf word en dan vir die huidige studie daargelaat word: "Functionalist sociological theory, otherwise known as structural-functionalism or equilibrium theory, envisions societies as systems with needs, in the service of which social behaviours are 'functional'. Functional theory often focuses on why societies remain stable over time" (Oakman 1991:153).

Die konflikbenadering fokus op die ontevredenheid van onderdruktes en openbaar die nadelige gevolge daarvan vir die sisteem. Die oorsaaklike karakter van konflikteorie kan skematies soos volg voorgestel word (Turner 1982:181; vgl Van Staden 1991:123-124):

\footnotetext{
2 Konflikteorie beskou die samelewing as konflik genererend as gevolg van die ongelyke verspreiding van hulpbronne (vgl Lenski 1966:43-93). Ongelykheid is dus die algemene bron van konflik (Turner 1982:181). Orde in die samelewing is die gevolg van die mag waarmee sekere mense verwag dat ander mense daaraan sal voldoen (Cohen 1968:21). Malina (1988:9) definieer konflikteorie as 'n perspektief waarvolgens menslike sosiale relasies ontwikkel, instand gehou word en verander omdat mense gemotiveer word om volgens hulle eie belange op te tree wat waarskynlik bots met die belange van ander. Konflikteorie verduidelik dus die sosiale orde in al die onderskeie aspekte, as ook die afbreek van die sosiale orde en die voorkoms van verandering. Samelewings is onstabiele sisteme - hulle verander voortdurend (Cohen 1968:169). Konflikteorie wil rekenskap gee van die oorsake van sosiale verandering. Die basiese vooronderstelling van die konflikteorie is die bestaan van een of ander klagte van persone dat hulle onderdruk word (Malina 1988:10; vgl Van Staden 1991:124).
} 


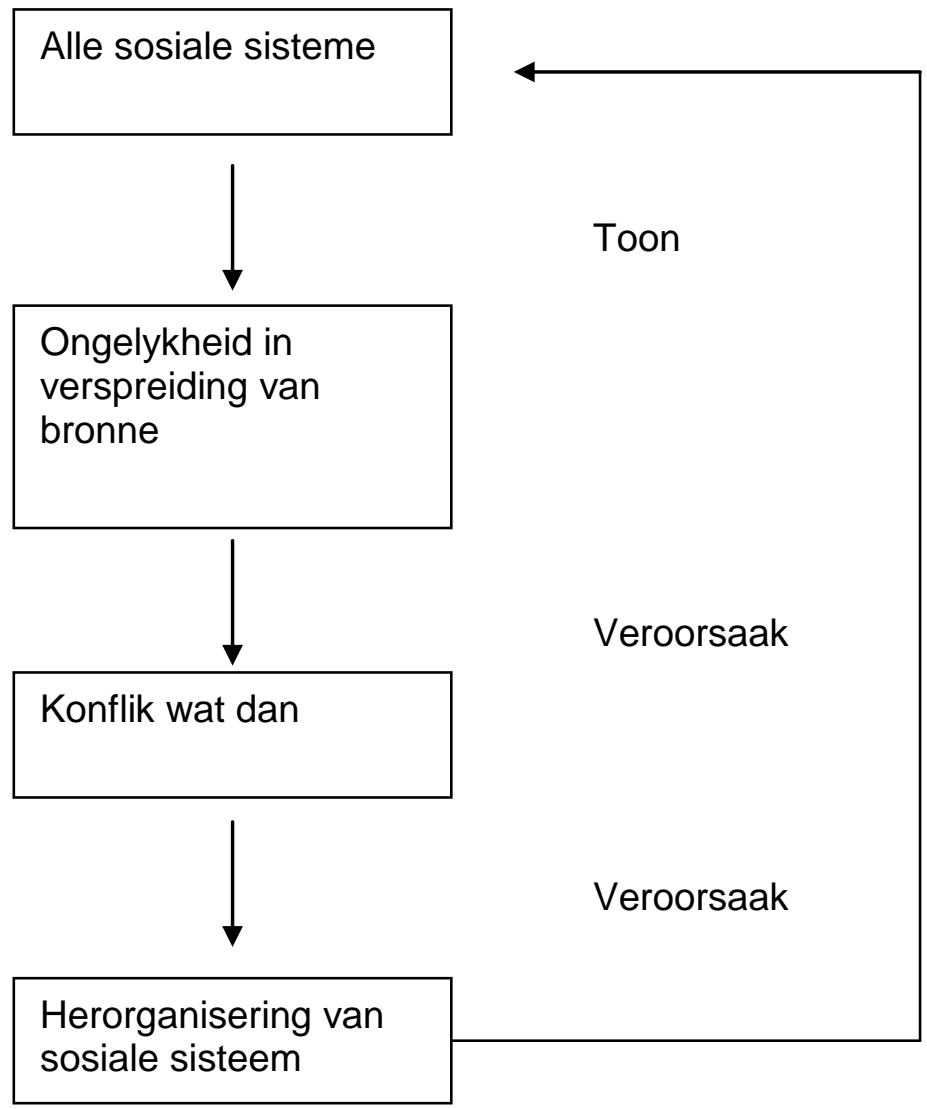

$\mathrm{Na}$ aanleiding van hierdie perspektief is keiser Augustus en die heersende groepe van die Romeinse Ryk die uitbuiters van die meerderheid landbouprodusente (state an instrument of oppression) (Oakman 1991:154). Die Romeinse Ryk het nie die materiële belange van die produsente gedien nie en het diep gewortelde vyandigheid en bitterheid in die sosiale verhoudings, veral tussen die stad en platteland, veroorsaak. Somtyds het openlike konflik as gevolg van vyandigheid uitgebreek. Militêre ingryping teen indringers, rowers en rebelle het gereeld plaasgevind (coersion). Ongelykheid en onderdrukking was nie deel van die oorspronklike natuur van dinge nie. Sosiale klasse is duidelik verdeel op die lyne van diegene wat het en diegene wat nie het nie; tussen diegene wat hulle nie bekommer oor wat hulle eet nie en diegene wat hulle wel daaroor bekommer; tussen diegene wat roof en verwoes en diegene wat nie voldoende vergoed word vir hulle arbeid nie (Oakman 1991:154). 


\title{
3. DIE AGRARIESE EKONOMIE
}

\subsection{Inleiding}

Ter inleiding kan gestel word dat die familie ${ }^{3}$ in die eerste eeu die primêre instelling van die samelewing was, teenoor die polities-ekonomiese instelling van die twintigste eeu (vgl Volschenk 2001: 261-268 oor die gevorderde agrariese samelewing). Oakman $(1991: 155 ; 156)$ stel die saak soos volg:

\begin{abstract}
Rather, ancient economic life was normally conducted within kinship or political instititions. Put in the technical jargon of cultural anthropology, what moderns think of as economic realities are in agrarian/peasant societies embedded in political or kinship contexts. .... By contrast, the ancient family tilled the soil or worked together to produce some specialized product. The home was the place of work. In fact, the Greek word "economy" (oikonomia) means "management of the household". In the rural village money transactions were rare. The usual course was bartering something of mutual value for something else, and then only with someone who was known by the family and trusted (like family)
\end{abstract}

Die grondeienaar of die owerheid (politieke instelling) het die familie gedwing om die produksie of produkte te betaal as huur of belasting. Die ekonomie as sosiale instelling het nie in die antieke samelewing bestaan nie.

\subsubsection{Die simplistiese agrariese samelewing}

Die simplistiese agrariese samelewing kan kortliks soos volg beskryf word (vgl Volschenk 2001:242):

$\overline{3}$ Van Aarde (1994:93) stel die saak soos volg:

In die voorindustriële wêreld van byvoorbeeld die Nuwe Testament het 'n mens dus wel ryker en armer klasse van mense aangetref. Dit is ook so dat hoe meer die agrariese samelewing weg van die horti-kulturele ( = die tydperk toe die mens van plante en diere sonder verbouing of teling geleef het) situasie ontwikkel het, hoe duideliker het die verband tussen sosiale status en rykdom geword. In so 'n gevorderde agrariese konteks (soos die van die Nuwe Testament) was die ekonomiese en sosiale klassesisteem egter steeds deel van die grotere sosiale sisteem waar familiale status belangriker was. Op die oppervlak kan dit dus lyk of politieke posisies en geld as statussimbole geag is. Dieperliggend egter het familiale strukture aanleiding tot bepaalde status gegee, wat op sy beurt tot politieke mag en rykdom gelei het. Om tot die aristokrasie te behoort, het dus sosiale status bepaal.

Die dominante rol van die familiale strukture binne die konteks van die gevorderde agrariese samelewing, soos byvoorbeeld die uitgebreide familie in 'n bepaalde dorpie, is 'n close unit. 
Een van die grootste ontwikkelings op sosio-ekonomiese gebied van die antieke tyd is die ontdekking van die ysterploeg en die gebruik van dierekrag. Dit het die mens in staat gestel om 'n surplus te produseer, in plaas daarvan om net in die onmiddelike behoeftes te voorsien. Saam met die tegnologiese ontwikkeling het ook nuwe sosioekonomiese probleme gekom, naamlik groter klasverskille en differensiasie. Die elite het groter mag verkry en al meer van die surplus produksie vir hulleself opgeëis. Baie kleinboere het hulle plase verloor en slawe geword as gevolg van skuld. Die situasie kan saamgevat word met die stelling dat al meer grond in die hande van al minder gekom het. Die bewerking van die grond is baie hoog gewaardeer en as primêre arbeid beskou. Die groter ontwikkeling op sosio-ekonomiese en politieke gebied het die ontstaan van groter weermagte tot gevolg gehad. As gevolg van die groter sosiale diversifikasie moes die elite 'n sterk weermag hê om hulle mag en prestige te beskerm en om al meer belasting en produksie middele van die meerderheid kleinboere te verhaal. Hierdie algemene faktore was van die belangrike invloede op die sosio-ekonomiese en politieke ontwikkelings in die antieke tyd

(die simplistiese agrariese samelewing - GV)

\subsubsection{Die gevorderde agrariese samelewing}

Die eerste-eeuse Mediterreense wêreld onder Romeinse heerskappy word beskou as 'n gevorderde agrariese samelewing. Die tydperk is gekenmerk deur hoë tegnologiese ontwikkeling en ontdekkings, waarvan die ontdekking van yster baie belangrik was. Die ekonomie staan op daardie stadium bekend as die bestaansekonomie. Die grondbesitters het die ekonomie beheer. As gevolg van te veel skuld het die kleinboere hulle grond verloor, wat in die hande van die afwesige grondeienaars beland het. Die afwesige grondeienaars het in die stede gewoon. Die stedelike ekonomie waarin die mag van die regeerders gesentreer was, het geparasiteer op die landelike ekonomie. Die landbousurplus is deur die elite ingepalm of deur belastings uitgeput. Die landelike ekonomie het op verskeie terreine in die stedelike ekonomie se behoefte voorsien. Die regerende elite het politieke stabiliteit probeer handhaaf, omdat die hele bestaansekonomie 
van die landbou afhanklik was. Die regerende elite in die stede het die landelike gebiede en die kleinboere geëksploiteer. Die stede was die middelpunt van die samelewing, sosio-ekonomies, polities en godsdienstig.

Die oorsig van die gevorderde agrariese samelewing (kyk afdeling 4.6 in Volschenk 2001:261-268) bevestig dat die familiale instelling die oorheersende instelling was (Malina 1981:94-121; Elliott 1991:88-120; Van Eck 1995:56-58). Die familie het 'n belangrike ekonomiese rol vervul en was die kleinste sosioekonomiese en godsdienstige bousteen. Die huwelik was primêr 'n patriargale sisteem waar die man gedomineer het. Die stratifikasie het in kompleksiteit toegeneem. Die regerende klas het al ryker geword en meer grond beheer, terwyl die kleinboere en landvolk al armer geword het. Die gevolgtrekking is dat die evolusie vanaf 'n hortikulturele na 'n simplistiese agrariese samelewing gekulmineer het in die gevorderde agrariese samelewing. Kenmerkend van laasgenoemde samelewing is die stryd om grondbesit, die stryd tussen die stad en die platteland, die sosiale stratifikasie en die sentraliteit van die familiale instelling.

\subsection{Die algemene aard van produksie in eerste-eeuse Palestina}

Ekonomiese antropologie help ons om die aard van die antieke ekonomie doeltreffend te konseptualiseer. Dit vestig ons aandag op die belangrike klemverskille en verskuiwing tussen die pre-industriële ${ }^{4}$ en die moderne industriële ekonomieë. Die volgende algemene prentjie word deur die

4 Die onderskeid tussen die pre-industriële stad en die industriële stad kan soos volg opgesom word (vgl Volschenk 2001:296):

Pre-industriële stad: Familie is ekonomiese eenheid. Spesialisering van produk. Sisteem vereis sosiaal en geografies ' $n$ vaste arbeidsmag. Spesialiste in die stad produseer die nodige goedere en dienste vir die stedelike elite. Stad en platteland is nie verbind deur middle van vloei van arbeidsmag en kapitaal of ' $n$ sentrale mag nie. Klein getal elite is die enigste mark. Hulle beheer die sentrale grond beheerstelsel en die godsdienste en politieke sisteem van belasting. Toegang tot stede word beperk deur die wette wat burgerskap bepaal - kleinboere word toegang verbied.

Industriële stad: Individu as werker; groot mobiele arbeidsmag wat los van geografiese en sosiale oorspronge kan werk. Spesialisering van arbeidsproses, kapitaal-intensief en koste effektief. Buigbare arbeidsmag vir werkgewers wat wil aanpas by veranderende marktoestande met minimum koste. Sodanige patroon verbind die stad en platteland. Baie noue relasie verseker vloei van kapitaal en arbeid na stede. Markte en kommunikasiekanale of vervoer sluit beide stad en platteland in stedelike sisteem waarin nodige rolle en uitruil gestruktureer en bevorder word. 
ekonomiese antropologie en ander vergelykende studies geskilder. Die ekonomieë van die vroeë Romeinse periode was grotendeels agrariese ekonomieë (Oakman 1986:18; Crosby 1988:21, 22; Fiensy 1991:vi, vii). Crosby (1988:21) stel dat ten spyte van die suksesse van die imperiale uitbreidings van en verstedeliking onder keiser Augustus, was die eerste-eeuse Romeinse ekonomie baie primitief. Geen ekonomiese struktuur of sisteem het bestaan nie. Crosby (1988:21; kyk ook Fiensy 1991:2) stel dat die antieke ekonomie 'n bestaansekonomie was. Landbou het die ekonomie oorheers, maar elke huishouding het slegs vir hulle eie gebruik geproduseer.

Die primêre beroep van meeste mense van die antieke gemeenskappe was die bewerking van die grond (Crosby 1988:21). Hierdie mense het op 'n bestaansvlak geleef en het nie geld gehad vir luukse items nie. Hulle produksie was primêr gerig op verbruik, behalwe as dit onteien was deur die dominante elite. Ekonomiese aktiwiteite in die antieke huishouding of dorp was ingebed in die sosiale struktuur. Oakman (1986:18) stel met reg dat daar 'n beperking was in die akkumulasie van rykdom (behalwe met belastinginvordering) en dat die huishouding die basis was vir ander sosiale en godsdienstige aktiwiteite. Met die landbouproduksie as die basis van die totale ekonomie, was ekonomiese verhoudings verbind met die natuur. Die natuur is beskou as onskeibaar van die bonatuurlike. As gevolg van die noue verbintenis tussen landbou-produksie, ekonomiese verhoudings en natuur, is produksie nie beskou as deur die mens beheer nie, maar deur goddelike kragte. Die sosiale orde en die natuurlike orde het oorvleuel; beide is afhanklik van die goddelike (Oakman 1986:20). Die goddelike was in die sentrum van die wêreld. Die bou van 'n huis het die oorspronklike skepping van die wêreld gereflekteer. Huisorde moes die oorspronklike orde van die skepping reflekteer. Israeliete het die skepping gesien as die huishouding van God. In hierdie huishouding was die hemel die troon van God en die aarde God se voetstoel (Matt 5:34-36). Geen mens se huis - selfs nie die tempel nie - het daarmee vergelyk nie. Die metafoor van die huis verteenwoordig 'n mikrokosmos van die heelal vir nie-nomadiese volkere. Die huis was die sentrum van die hele kosmos vir die tradisionele volkere. 
Gespesialiseerde pottebakkerswerk, wapens en ander goedere is deur klein familiebelange, veral in die hawestede van die Mediterreense gebied, geproduseer. Antieke kleinboere het van vroeg af reeds hulle eie gereedskap en klere gemaak. Spesialisering in die dorp was relatief beperk. Weens geldgebrek by die kleinboere, was die mark relatief beperk tot die bevoorregtes met toegang tot surplus fondse. Die mark is uitgebrei net om nog meer elite te inkorporeer. Produksie in die antieke tyd was dus onderwerp aan sekere sosiale en tegniese beperkings. As gevolg van die hoë vervoerkostes, was handel beperk tot wyn, olie en ander maklik vervoerbare goedere van hoë waarde. Meeste areas moes seker maak dat sekere basiese ekonomiese goedere plaaslik beskikbaar was. Die antieke ekonomie het bestaan uit drie standaard produksiefaktore, naamlik grond, arbeid en kapitaal. Die agrariese ekonomie was afhanklik van die land om voedsel en ander produkte te produseer. Mense en diere was die belangrikste arbeidskrag. In plaas van kapitaal kan ons in die antieke ekonomie verwys na die tegnologie wat beskikbaar was vir die produksieproses (vgl Oakman 1986:19, 20).

\subsubsection{Grond en geografiese bepalings van produksie}

Boerdery word grotendeels bepaal deur die heersende fisiese omstandighede. Plat lande of bergagtige terrein bepaal in 'n groot mate die uitleg van die landerye en die vestigingspatroon. Galilea self word verdeel in 'n bo en onder-Galilea. Bo-Galilea was ruwe en bergagtige terrein, relatief ontoeganklik, maar bied goeie boerderygeleenthede. Onder-Galilea bestaan uit vrugbare valleie en die Esdralonvlakte. Onder-Galilea is ekstensief en intensief bewerk. Die landerye rondom die see van Galilea vorm die noordelike deel van die Jordaanvallei en was baie vrugbaar gewees. Alhoewel Judea en Galilea van mekaar onderskei word, het hulle belangrike geografiese eienskappe wat hulle met ander Mediterreense lande in gemeen het. Geologies word 'n driedeling gemaak van die Mediterreense land, naamlik spoelgrondvlakte, tersiêre hange en die berge. Die tersiêre grond is geskik vir gewasse, die hoër lande is beplant, die laer lande is gesaai en op die spoelgrond was die vee (Oakman 1986:19, 20). Galilea het 
'n hoër reënval gehad as Judea, maar ten spyte daarvan is daar droëgrond boerdery bedryf. Die basiese probleem was om genoeg vog in die grond te behou om elke jaar gewasse te verbou Die antieke Palestynse kleinboere het hulle bergagtige grond so bewerk, dat hulle gronderosie kon voorkom en die meeste van die bietjie winterreëns kon opvang. Sosiale organisasie, veral in die lig van die plaaslike en die streek se selfsorgsaamheid, het in 'n mate die geografiese determinante getemper (kyk Stegemann \& Stegemann 1999:7-14).

\subsubsection{Organisering van arbeid en arbeidsinsette}

Crosby $(1988: 14,15)$ verwys na die verdeling van arbeid as een van die sosiale koördinasieprobleme. Mense ervaar herhalende probleme in hulle poging om saam te leef. Vanuit die metafoor van die huishouding omsluit hierdie probleem drie dimensies van menslike relasies in en rondom die oikia/oikos naamlik: die probleem van gesag, die verdeling van arbeid en die toewysing van goedere en dienste. In primitiewe gemeenskappe is gesag niks meer as wie maak die voorstelle en wie gaan dit navolg nie. Die verdeling van arbeid handel weer oor wie gaan watter werk doen, hoe en wanneer. Die probleem van die toewysing van goedere is om dit wat beskikbaar is in die gemeenskap en die verspreiding van goedere en dienste onder die lede wat dit kollektief vervaardig het, te distrubeer.

Die kleinboerhuisgesin was die kern van die arbeidsmag van die antieke agrariese ekonomie. Hierdie werksmag is aangevul deur diere en slawe. In Palistina het slawerny nie 'n groot rol gespeel ten opsigte van produksie nie. Dit was meer vrybesittersarbeid. Later het die elite van die Romeinse Ryk die besitters of kleinboere beskou as menslike beeste, slegs as gereedskap of lewende hawe van die Romeinse landgoed (Fiensy 1991:75; Lenski 1997:200).

Die noodsaaklike verdeling van arbeid in die kleinboergemeenskap het baie spanning veroorsaak by die huishoudings van individuele kleinboere. Binne die huishouding is daar verdere rolverdelings tussen wat mans, vrouens en kinders moet doen. Die man het homself regdeur die jaar primêr met landboutake besig gehou. Die vrou het voedsel voorberei, klere gemaak en die 
kinders opgevoed. Die ouer kinders en vrouens het ook wanneer nodig, in die veld gewerk. Op dorpsvlak word algemene gereedskap en arbeid gedeel tussen huishoudings op die basis van gebalanseerde resiprositeit.

Palestina in die Grieks-Romeinse tyd het 'n groter verdeling van arbeid ervaar binne die dorpe en gemeenskap sowel as 'n vorm van bemarking. Die bemarking is aangemoedig deur die uitbreiding van die geldvolume en die verhoging in die uitruil van geld. Die rykes het druk toegepas ten opsigte van kontantverbouing. Hierdie ontwikkelinge was ondergeskik aan die pre-industriële ekonomie van daardie tyd. Reisende ambagsmanne het van die noodsaaklike vaardighede verskaf wat in die stede nodig was. Groter verdeling van arbeid in die landelike gebiede is veroorsaak deur werkloosheid en die aanvraag na arbeid op groter plase. Die agrariese ekonomie wat hierbo beskryf is, het 'n groot aantal arbeiders vereis. Die arbeiders van groot landgoed het die grond vir die rykes bewerk en 'n deel van die opbrengs vir hulle gegee. Hulle was goedkoop arbeiders, huurders, dagloners of landbouslawe. Die grondeienaars daarteenoor was ryk of welvarend, alhoewel die produksie van die gemiddelde werker klein was.

In die Grieks-Romeinse bronne was huurders algemeen bekend. Hulle het gewoonlik nie self grond besit nie en was verplig om 'n huurkontrak met 'n grondeienaar aan te gaan om die grond te bewerk. Hulle het huur betaal vir die gebruik van die grond. Die huur is op een van drie maniere betaal:

- 'n vaste bedrag (in opbrengs of kontant);

- 'n deel of persentasie van die oes; en

- deur middel van arbeid (bewerking van die grondeienaar se eie grond), (vgl Fiensy 1991:75)

Intensiewe bewerking was die norm in die eerste-eeuse Palestina. Die landboukalender is algemeen bekend vanuit Hebreeus/Joodse en Romeinse bronne. Die kombinasie van landbou, wingerdbou en boomkwekery in al die 
Mediterreense lande het beteken dat die werkslas eweredig versprei was deur die jaar.

\subsubsection{Tegnologie en verbouing}

Die gereedskap van die antieke tyd was relatief simplisties. Daar was baie min innovasie, omdat daar geen beloning was vir surplus produksie nie. In die Grieks-Romeinse tyd is enige surplus deur belasting of die grondeienaar opgeëis. Landbouvooruitgang was alleen moontlik waar persoonlik voordeel in die wins gegeld het, byvoorbeeld vir soldate wat die oorwinning behaal het. Die Masedoniese soldate-setlaars van die Ptolemese tyd of die Romeinse koloniste dien as voorbeeld. Sodanige tye het in die antieke tyd nie lank geduur nie (kyk Oakman 1986:25).

Verskillende gewasse is in Palestina verbou. Die hoof bestaansgewasse was koring, druiwe, olywe en vye. Deuteronomium 8:8 wys tereg op die gewasse van Palestina. Die koms van die Grieke en die Romeine het die landbougewasse uitgebrei. Graan het die stapelvoedsel van die meerderheid mense in Palestina gebly. Die gemiddelde opbrengs in Palestina was vyf voudig. Daar is baie geploeg voordat daar gesaai is, min of meer drie keer. In die afwesigheid van besproeiing, het die lae reënval van Palestina vereis dat die helfte van die lande braak moet lê om sodoende die vog gehalte terug te ploeg in die grond. Die Joodse sabbatsjaar was 'n verpligte godsdienstige braaklegging van die grond. Die Romeinse landbouers het groot sorg gegee aan die wingerde, omdat dit vir die Romeinse elite 'n kontantverbouing was (Oakman 1986:26).

\subsection{Drie vorme van distribusie in pre-industriële ekonomieë}

Oakman (1986:78-79; vgl Carney 1975:138-140) verwys na die drie vorme van verspreiding in die pre-industriële ekonomie. 


\subsubsection{Redistribusie deur 'n sentrale instelling}

Redistribusie verteenwoordig die insameling, berging en herverdeling van goedere en dienste wat bepaal word deur een of ander sentrum (owerheid of tempel). Belasting en rente was gewoonlik die primêre vorm van redistribusie. Bogenoemde beskryf genoeg-saam wat gebeur as huur, belasting en tiendes vanaf die landbouprodusente af na die stedelike gebiede, tempel en staatskoffers, gestuur word. Die geld word vandaar na ander plekke gekanaliseer vir spesifieke doelwitte, in plaas van om die produsente se behoeftes te bevredig. Die sentralisasieproses het gelei tot verdere sentralisering van ander sosiale aangeleenthede - die groei van groot eiendom en toenemende getalle van groot grondbesitters, asook die toename in afhanklike huurders.

Elliott (1991:220) toon aan dat die tempel die omvattende, sentrale instelling was waardeur beheer uitgeoefen is oor alle aspekte van die Joodse politieke, ekonomiese, sosiale en kulturele lewe. Die godsdienstige outoriteite het vanuit die tempel as ekonomiese instelling, onregverdig en onderdrukkend opgetree. Die verspreiding deur middel van 'n sentrale instelling het die ontstaan van hiërargiese en antagonistiese klasseverhoudings veroorsaak. Die priesters en godsdienstige leiers het deur middel van belasting, tiendes en offers hulle ekonomiese mag misbruik ten koste van die magteloses.

In 'n tempelgebaseerde ekonomie word die surplus landbouproduksie sentraal geakkumuleer en versprei. Die vorme van sosiale relasies (insluitende ekonomiese handelinge) in pre-industriële gemeenskappe wissel tussen die twee pole van resiprositeit (huishouding-gebaseerd) aan die een kant, en redistribusie (tempel-gebaseerd) aan die ander kant (Sahlins 1965:226; Malina 1986:98-111; Moxnes 1987:1-35, 1988:68-88; Elliott 1991:230-239). Redistribusie is tipies van grootskaalse samelewings met sentraal geakkumuleerde ekonomieë soos die tempelgebaseerde samelewings van Mesopotamië, Egipte, Palestina en Rome (vgl Carney 1975:171-175; Elliott 1991:233). Die onderskeidende kenmerke van politieke ekonomieë is die opeenhoping van goedere en dienste in 'n sentrale sentrum, veral die tempel. Vanuit hierdie sentrum is politieke beheer en verspreiding deur die magtige elite of tempel hiërargie uitgevoer (kyk Elliott 1991:233). 
Ekonomiese en sosiale relasies is asimmetries en gestratifiseerd volgens norme wat die elite bevoordeel. In bogenoemde sosiale relasies word onderdanigheid en afhanklikheid beheer deur:

- 'n konsolidering van politieke, legalistiese en militêre mag;

- die toepassing van sosiale stratifikasie en grense (boundaries); en

- die kulturele (insluitend, godsdienstige) tradisies (Elliott 1991:233).

Elliott (1991:234) kontrasteer die ekonomiese relasies van resiprositeit met dié van redistribusie. Redistribusie word soos volg beskryf:

- Central storehouse economy with temple depot

- Centralized control of production, distribution, consumption of resources and services

- Redistribution of available surplus according to interests of power wielders

- Economic and social imbalance of "haves/have nots", elites and subelites according to control of resources means, and relations of production.

\subsubsection{Resiprositeit}

Resiprositeit omsluit 'n soort implisiete, nie-legalistiese, kontraktuele verpligting tussen twee mense (of groepe mense) wat afdwingbaar is deur kodes van eer en/of skande. Die huishouding dien as begronding van die verhoudings van resiprositeit. Die huishouding het 'n groot rol gespeel in die geskiedenis, omdat groot hoeveelhede goedere geproduseer is deur die huisgesin vir die familie se gebruik. Die familie was 'n geslote groep. Die beginsel was altyd dieselfde, naamlik produsering en berging vir die bevrediging van die behoeftes van die groep. Binne hierdie tradisionele eerste-eeuse ekonomie, was daar interaksie tussen huishoudinglede met mekaar en deur middel van hulle bronne, in so 'n mate dat hulle as 'n breë gemeenskap gefunksioneer het (Oakman 1986:79).

Die verspreiding van welvaart het vir baie eeue op 'n horisontale vlak geskied. Oakman (1986:79; 1991:157; vgl Elliott 1991:232) tref onderskeid 
tussen algemene resiprositeit, gebalanseerde resiprositeit, en negatiewe resiprositeit.

- Negatiewe resiprositeit beteken om aan ander te doen wat jy nie aan jouself gedoen wil hê nie. Dit is die etos van vyandigheid en oorlog teenoor nie-bloed-verwante of vyande.

- Gebalanseerde resiprositeit is die uitruil van ekonomiese goedere of arbeid met ander huishoudings op 'n quid pro quo basis.

- Algemene resiprositeit beskryf die gee van geskenke sonder om iets terug te verwag. Hierdie tipe uitruil is beperk vir baie naby familie of dit help om goeie verhoudings te bou met seremoniële familie.

Die ekonomiese relasie van resiprositeit staan teenoor redistribusie via die tempel. Die resiproke relasies sluit persoonlike en wedersydse uitruil van goedere en dienste in. Dit kom gewoonlik voor in plattelandse gemeenskappe, stam-organisasies en in huishoudings (kyk Elliott 1991:232).

Die sosiale toestande waaronder die drie verskillende tipes resiprositeit geskied, word bepaal deur die nabyheid (persoonlik en geografies) van die agente en die doel, wyse, plek en tyd van die interaksies. Huishoudings, families en fictive kin groepe het gereeld algemene resiprositeit beoefen, wat die nabyheid van sosiale bande getoon het en hulle wedersydse sorg en ondersteuning aan mekaar (Elliott 1991:232-233).

In teenstelling met die ekonomiese relasies van redistribusie, is die volgende ekonomiese relasies kenmerkend van resiprositeit:

Diffused, local "household" management;

Household control of production etc.

Reciprocal exchange of goods and services according to their availability and need;

Balanced relations through mutual sharing of goods at common disposal.

(Elliott 1991:234) 


\subsubsection{Verspreiding deur die mark}

In die antieke tyd was daar nie 'n mark in die ware sin van die woord nie. Verspreiding deur die mark het beteken dat die groot stede die surplus produksie van die kleinboere, soos 'n groot magneet, opgeëis het. Die groot stede het die platteland geëksploiteer. Oakman (1986:79) verduidelik hierdie eksploitasie soos volg:

The powerful forces of exploitation that accopanied the birth of the Roman empire undoubtedly disturbed village relationships and threatened ancient economic values through the impoverishment of the cultivator and expropriation. The "gravitational effects" of powerful economic centres upon decentralized economic activity were irresistable.

Redistribusie het mag benodig wat weer die verspreiding deur resiprositeit binne familieverwantskappe versteur het. Dit het 'n oorleweringsmentaliteit in die dorpe tot gevolg gehad, sowel as toenemende konflik tussen huishoudings en selfs strenger berekening van uitruiling en skuld. Die kleinboere se probleem was om die eise van die eksterne wêreld te balanseer met die selfvoorsiening aan die eie huishouding. Die boer het een van twee keuses gehad naamlik: om die produksie te verhoog, of om die uitgawes te beperk. By die nalaat hiervan, is die kleinboer vasgevang in 'n spiraal van skuld wat gelei het tot die verlies van grond. Die gebrek aan landbougrond was een van die meer belangrike oorsake van Joodse onrus voor die Joodse oorlog. Onteiening van kleinboere se grond en ' $n$ toename in kinders onder die kleinboere het gelei tot die relatiewe oorbevolking van Palestina. Palestynse kleinboere het met die heidense setlaars in Galilea en Perea gebots, omdat hulle dit as 'n direkte bedreiging van hulle eie ekonomiese belange beskou het en die diefstal van hulle grond deur heidene. Saam met hierdie stryd, het die Selote en die rowers die vriende van die Romeinse aristokrasie verag. Hierdie "ondersteuners" (retainers) van die Romeinse mag was diegene wat die belasting ingevorder het, beslag gelê het op hulle grond en in die oë van die Palestynse kleinboere die wet van God verwerp 
het. Dit was in hierdie agrariese konfliksituasie waarin Jesus van Nasaret die koms van die Koninkryk van God verkondig het (vgl Crossan 1998:177-238; Hanson \& Oakman 1998:63-130; Patterson 1998:63, 112-118).

\section{4. 'N HOLISTIESE EN SISTEMIES-INTERRELASIONELE MODEL}

\section{1 'n Holistiese raamwerk van die sosio-historiese agtergrond van die eerste-eeuse Mediterreense wêreld}

Die doel van die navorsing is om aan te toon dat die sosio-ekonomiese agtergrond van die eerste eeu die konteks is waarbinne land- en grondbesit verstaan moet word. Die sosio-ekonomiese agtergrond behoort verstaan te word binne die geheelperspektief van die eerste-eeuse Mediterreense samelewing. Elliott (1986:14-20) gee in aansluiting by Carney (1975) 'n deeglike uiteensetting van die holistiese raamwerk. Die sosiaal-wetenskaplike model omsluit alle faktore wat die land en ekonomie van die eerste-eeuse Mediterreense wêreld inkorporeer. Die primêre boustene van die model is die familie, gondbesit of grondonteiening, die verhouding van die pre-industriële stad teenoor die platteland en die sosiale stratifikasie van die eerste-eeuse samelewing. Alhoewel die boustene afsonderlik hanteer is, is die model 'n integrerende geheel en kan die elemente slegs onderskei word en nie geskei nie. Die huisgesin het verbrokkel as gevolg van die stryd tussen die elite en aristokrasie vanuit die stad teen die kleinboere en landvolk op die platteland. Grond is die primêre bron van konflik, omdat dit die belangrikste ekonomiese middel was in die gevorderde agrariese samelewing. Die elite het die kleinboere swaar belas en veroorsaak dat hulle skuld groter word. Die enigste uitweg uit die bose kringloop was om hulle grond aan die afwesige grondeienaars te verkoop. Die tragiese einde van sommige huisgesinne was dat hulle hulleself as slawe verkoop het om ekonomies te oorleef. Die sosiale stratifikasie model van die eerste eeu is ingebed in die stryd om grondbesit. Die holistiese model van Elliott (1986:14) is 
saamgestel uit 'n verskeidenheid van bronne, insluitende Sjoberg (1960), Theissen (1978), Carney (1975) en Lenski (1991). Carney (1975:45-281) het die kruis-kulturele model in detail behandel, insluitende die historiese en sosiale data waarop die model berus. Die model kan saamgevat word as 'n sistemiesinterrelasionele model (Elliott 1986:14).

\section{2 'n Sistemies-interrelasionele model}

Die navorsing van die sosiale realiteit vereis 'n sistemiese analise van die sosiale sisteem as 'n geheel. Die data sluit alle groot subsisteme in, naamlik ekonomie, ??sosiaal, politiek en kultuur. Die model sluit verder die interne struktuur, waardes, norme, rolle, instellings en sosiale prosesse in, asook die toestande van die natuurlike omgewing en voorafgaande sosio-historiese gebeure. Elliott (1986:13) beskryf die sistemiese interrelasie tussen die onderskeie sektore en die doel van die model soos volg:

Such a model uses available historical and social data to construct a general outline of an institution or a whole society, in our case Palestinian society, its chief sub-systems and the pattern of their interrelationships. Its purpose is to represent the major components of a total social system, to facilitate understanding of the relation of social structures and processes, to enable comparisons and contrasts across cultures and periods, to control and eliminate erroneous, culture-based assumptions of researchers, and to provide a framework for interpretation and the gathering of still further data.

(my kursivering - GV)

Die buigbare interrelasies tussen die verskillende sektore van die model verteenwoordig die primêre instellings van die pre-industriële agrariese gemeenskappe en hulle dinamiese interrelasie. Die model is ' $n$ holistiese raamwerk waarbinne data gesoek, georganiseer en geïnterpreteer kan word (Elliott 1986:16). 


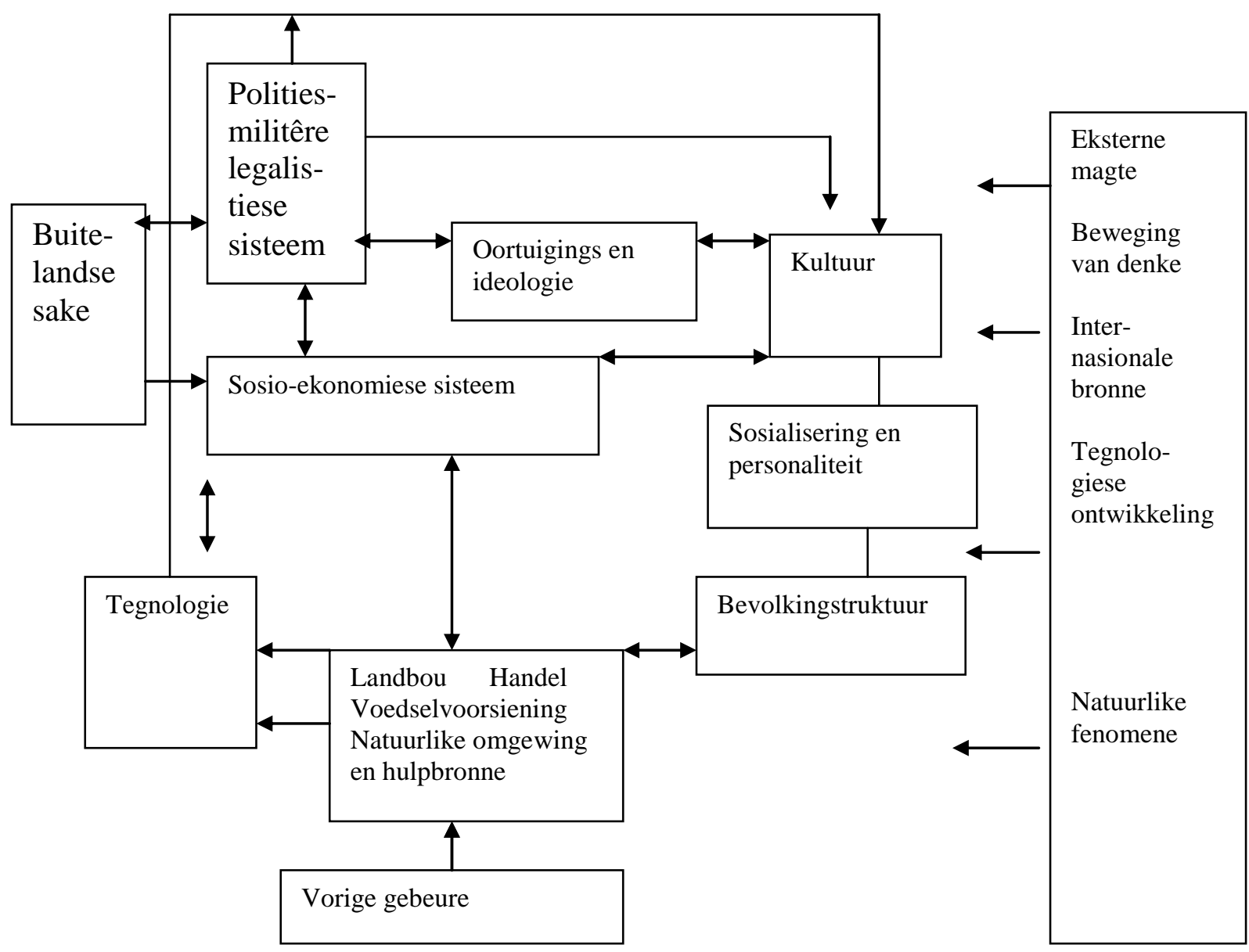

\subsection{Palestina as pre-industriële gemeenskap}

In pre-industriële Palestina was daar nie 'n afsonderlike godsdienstige sektor met afsonderlike instellings, organisasies en sosiale aktiwiteite nie. Godsdiens was ingebed in al die sektore van die sisteem as 'n geheel. Die model toon die onderskeid tussen die eerste eeu en die twintigste eeu duidelik aan en voorkom die dwalings van anakronisme en etnosentrisme. Godsdienstige fenomene in die antieke wêreld moet binne die totale raamwerk van die sosiale en kulturele fenomene verstaan word, asook die wyse waarop die simbole die vloei van die totale sosiale lewe beïnvloed het. Die godsdienstige fenomene sal dus in al die sektore van die diagram van ons model verteenwoordig wees. Die navorser moet bepaal hoe hulle die persepsies, gevoelens, botsende belange, waardes, 
norme, sosiale reëlings en prosesse van die sosiale sisteem as geheel vorm en wedersyds daardeur gevorm word (kyk Elliott 1986:16).

\subsection{Die ekonomiese instellings}

Die model beklemtoon die belangrikheid van die ekonomiese basis van die eerste-eeuse Palestina. Die volgorde van ekonomie, ekologie, politiek en kulturele faktore is van deurslaggewende belang. Die model reflekteer 'n superstruktuur van die gemeenskap wat bestaan uit politiek, geloofsisteem, ideologie en kultuur. Dit is gebaseer op en word beïnvloed deur die ekonomie, produksieverhoudings en verbruik. Hierdie model, van onder na bo beskou, verteenwoordig die teorie in verband met die verhouding van die superstruktuur tot die infrastruktuur. Hierdie benadering analiseer die primêre belang van die materiële basis en ekonomiese relasies van die Palestynse lewe, die verband met die sosiale orde van kollektiewe optredes, en dan met die wyse van politieke beheer en simboliese verteenwoordiging (vgl Elliott 1986:16-17).

\section{SAMEVATTING}

Die huishouding en stad of platteland is 'n integrale deel van die breë ekonomiese sisteem van die eerste-eeuse Mediterreense wêreld. Alhoewel die woord ekonomie in bogenoemde konteks 'n contradictio in terminus is (kyk afd 5.2.1; 5.7.1 in Volschenk 2001:284, 285, 341, 342), kan die term wel sinvol gebruik word. In afdeling 3 het dit duidelik geblyk dat die huisgesin die primêre ekonomiese entiteit is. Die bewerking van grond of landbou het die kern van die bestaan van die huisgesin gevorm. Die agrariese ekonomie was ingebed in die familiale instelling. Die landbouproduksie is as integrale deel van die sosiale struktuur aangetoon. Grond, asook ambagte, is binne die familie van geslag tot geslag oorgelewer. Die ekonomie was nie markgerig nie, alhoewel daar al 'n mate van handel in produkte bestaan het. Geografie het ook 'n rol gespeel in die vasstelling van waar en wanneer wat geproduseer is.

Die organisering van arbeid het primêr binne die huisgesin plaasgevind. Ambagte en spesialiteite is van geslag tot geslag binne die familie oorgelewer. 
Die huisgesin was dus die primêre arbeidsmag, maar dierekrag en slawe is ook gebruik. Die agrariese ekonomie het 'n groot arbeidsmag vereis. As gevolg van die oneweredige verspreiding van grond en die verknegting van die kleinboere deur belasting en rente, het die afwesige grondeienaars groter mag en beheer uitgeoefen oor die kleinboere, dagloners en slawe. Die ontwikkeling en uitbreiding op sosiale gebied het intensiewer bewerking van die grond vereis. Die ontdekking van die ysterploeg en die inspan van dierekrag het surplus produksie tot gevolg gehad wat nodig was om in die behoeftes van die stede en elite te voorsien.

In afdeling 3.3 is die verspreiding van die produksie in die pre-industriële ekonomie bespreek. Die redistribusie deur 'n sentrale instelling is kenmerkend van die pre-industriële ekonomie waar die surplus produksie deur die elite vanaf die plattelandse kleinboere na die stede gekanaliseer is. Die beweging van goedere en dienste na die stad as sentrum is oortuigend aangetoon. Die redistribusie het die sosiale stratifikasie en konflik geïntensifiseer en dit het gelei tot groter differensiasie. Die druk op die huisgesin het verhoog en die spanning tussen die stad en platteland het toegeneem.

Resiprositeit staan teenoor redistribusie. Resiprositeit fokus pimêr op die verspreiding van middele onder huisgesinne en uitgebreide familie wedersyds. Resiprosi-teit is ook beperk tot die onmiddelike omgewing, byvoorbeeld of net op die platteland of net in die stad. Die antieke ekonomie was nie 'n markgerigte ekonomie in die ware sin van die woord nie. In afdeling 3.2.3 is die eksploiterende effek wat die elite en die stede op die plattelandse kleinboere gehad het, weer eens beklemtoon. Die uiteinde van die eksploitasie was die kleinboeropstande wat gegrond was op die opponerende persepsies oor grondbesit.

Die primêre boustene van die eerste-eeuse Mediterreense samelewing binne die holistiese of sistemies-interrelasionele model is die familie, grondbesit, die pre-industriële stad of platteland en die sosiale stratifikasie. Die gevolgtrekking is dat binne die agoniese samelewing die familie verbrokkel het en van die kleinboere hulle grond verloor het as gevolg van skuld en eksploitasie deur die elite. Die sosiaal-wetenskaplike model beklemtoon die ekonomiese 
basis van die pre-industriële samelewing en die kultuur-historiese afstand tussen die antieke en moderne wêreld.

\section{Literatuurverwysings}

Carney, T F 1975. The shape of the past: Models and antiquity. Kansas: Coronado Press.

Cohen, P S 1968. Modern social theory. London: Heinemann Educational Books.

Crosby, M H 1988. The house of disciples: Church, economics and justice in Matthew. New York: Orbis Books.

Elliott, J H 1986. Social-scientifc criticism of the New Testament: More on methods and models. Semeia 35, 1-33.

Elliott, J H 1988. The fear of the leer. The evil eye from the Bible to Li'l Abner. Forum 4(4), 42-71.

Elliott, J H 1991. Temple versus household in Luke-Acts: A contrast in social and symbolic realities, in Neyrey $\mathrm{J} \mathrm{H}$ (ed), The social world of Luke-Acts: Models for interpretation. Minneapolis: Fortress. (also in HTS 47, 88120.)

Fager, J F 1993. Land tenure and the Biblical Jubilee: Uncovering Hebrew ethics through the sociology of knowledge. (JSOT Suppl series 155.)

Fiensy, D A 1991. The social history of Palestine in the Herodian period. Lewiston, NY: Edwin Mellen. (Studies in the Bible and early Christianity 20.)

Hanson, K C \& Oakman, D 1998. Palestine in the time of Jesus: Social structures and social conflicts. Minneapolis: Fortress.

Lenski, G, Lenski, J \& Nolan P (1970) 1991 [1997]. Human societies: An introduction to macrosociology. Sixth Edition. New York: McGraw-Hill.

Lenski, G E 1966. Power and privilege. New York: McGraw-Hill.

Malina, B J 1981. The New Testament world: Insights from cultural anthropology. Atlanta: John Knox.

Malina, B J 1988. A conflict approach to Mark 7. Forum 4(3), 31-62. 
Moxnes, H 1987. The economy in the Gospel of Luke in light of social anthropology, in Moxnes, $\mathrm{H}$ (ed), Economy in the New Testament, 1-35. (Urkristendommen: Prosjektshefte 2.)

Moxnes, H 1988. The economy of the Kingdom: Social conflict and economic interaction in Luke's gospel. Philadelphia: Fortress.

Oakman, D 1986. Jesus and the economic questions of his day. Lewiston: Edwin Mellon. (SBEC 8.)

Oakman, D 1991. The countryside in Luke-Acts, in Neyrey J H (ed), 151-179. Peabody, MA: Hendrickson.

Sahlins, M D 1965. On the sociology of primitive exchange, in Banton, M (ed), The relevance of models for social anthropology. London: Tavistock. (Association of Social Anthropologists Monographs 1.)

Sjoberg, G, 1960. The Preindustrial city: Past and present. New York, NY: MacMillan.

Stegemann, E W \& Stegemann, W 1999. The Jesus movement: A social history of its first century. Edinburgh: $T$ \& $T$ Clark.

Theissen, G 1978. Sociology of early Palestinian Christianity. Philadelphia: Fortress.

Turner, J H 1982. The structure of sociological theory. $3^{\text {rd }}$ ed. Illinois: Dorsey.

Van Aarde, A G 1994. God-with-us: The dominant perspective in Matthew's story. Pretoria: Gutenberg. (HTS Supp/5.)

Van Eck, E 1995. Galilee and Jerusalem in Mark's story of Jesus: A narratological and social scientific reading. Pretoria: Tydskrifafdeling van die Ned Herv Kerk. (HTS Suppl 7.).

Van Staden, P 1991. Compassion - The essence of life: A social-scientific study of the religious symbolic universe reflected in the ideology/theology of Luke. Pretoria: Tydskrifafdeling van die Ned Herv Kerk. (HTS Supp/4.)

Volschenk, G J 2001. Eksegeties-metodologiese vooronderstellings van die ondersoek na die ekonomie in die leefwêreld van Matteus: Toegepas op land, grondbesit en die jubilee. DD proefskrif, Universiteit van Pretoria. 